\title{
Revolution blues: the reconstruction of Health and Safety as a 'common-sense' form of regulation
}

Article

Accepted Version

Almond, P. (2015) Revolution blues: the reconstruction of Health and Safety as a 'common-sense' form of regulation. Journal of Law and Society, 42 (2). pp. 202-229. ISSN 0263323X doi: https://doi.org/10.1111/j.1467-6478.2015.00705.x Available at https://centaur.reading.ac.uk/39604/

It is advisable to refer to the publisher's version if you intend to cite from the work. See Guidance on citing.

To link to this article DOI: http://dx.doi.org/10.1111/j.1467-6478.2015.00705.x

Publisher: Wiley-Blackwell

All outputs in CentAUR are protected by Intellectual Property Rights law, including copyright law. Copyright and IPR is retained by the creators or other copyright holders. Terms and conditions for use of this material are defined in the End User Agreement.

www.reading.ac.uk/centaur 
Central Archive at the University of Reading

Reading's research outputs online 


\title{
Revolution Blues: The Reconstruction of Health and Safety Law as \\ 'Common-Sense' Regulation
}

\begin{abstract}
PAUL ALMOND*
This paper reviews the last five years of Coalition Government policymaking in relation to occupational health and safety law. It shows that the most significant and influential element of this activity has been the reframing of the wider regulatory system according to a dominant ideological paradigm of 'common-sense' regulation, to the detriment of other considerations and interests. A social constructionist framework assists in setting out the means through which this new 'symbolic universe' of regulatory possibility has been constructed and promulgated within the policymaking arena. In particular, it identifies the key role played by processes of deliberative regulatory engagement in the construction and development of this approach, and identifies the inherent vulnerability of 'thin' forms of deliberation to this sort of application.
\end{abstract}

\section{INTRODUCTION}

Like many other fields of government activity, the last five years have seen those involved in the regulation of health and safety in the United Kingdom having to contend with the challenges posed by a sustained economic recession and a crisis of the public finances. ${ }^{1}$ The institutional change heralded by the election of a Conservative-Liberal Democrat coalition

\footnotetext{
* School of Law, University of Reading, Foxhill House, Whiteknights Road, Reading RG6 7BA, UK. p.j.almond@ reading.ac.uk

I have gratefully benefited from the comments of many people while writing this paper, including Steven Bittle, Carmen D'Cruz, Neil Gunningham, Richard Hyde, Stuart Lakin, Nancy Reichmann, David Whyte, and the three JLS reviewers; all errors remain my own.

${ }^{1}$ T. Prosser, "“An Opportunity to Take a More Fundamental Look at the Role of Government in Society": The Spending Review as Regulation' (2011) Public Law 596; P. Taylor-Gooby, 'Root and Branch Restructuring to Achieve Major Cuts: The Social Policy Programme of the 2010 UK Coalition Government', (2012) 46 Social Policy \& Administration 61.
} 
government in 2010, and a subsequent shift towards a new 'politics of austerity', have led to a 'rolling back' of regulatory resourcing and formal intervention, as well as reform of the legal and institutional frameworks which govern regulatory activity. ${ }^{2}$ Together, these developments might be read as a product of external circumstances which have conspired to compromise the foundations of the existing regulatory structure. But this is only a partial explanation for the changes that have taken place during the last five years, in that it overlooks the profoundly ideological character of many of these changes. These post-2010 policy developments have profoundly reshaped both the substantive content of the health and safety regulatory system, and also the tenor of social debate around this issue. As such, and as the current Government's term of office comes to an end, the time is ripe for an assessment and review of some key features of the last five years of policymaking in this area.

These recent developments merit attention because they provide an instructive example of a particular dynamic of reform. A pre-existing commitment to specific political values, such as deregulation and business freedom (which, it is claimed, reflect public preferences for economic liberalism), has been translated into policy in a particularly pervasive manner which has reframed the debate about the form that regulation ought to take. Perhaps unlike previous eras of government hostility towards health and safety regulation, when opposition was at least recognised and understood as such, this more recent period has seen the creation of a new orthodoxy, or 'common-sense', 3 of regulation which sets firm parameters around what is possible and permissible in terms of future policy, and which excludes alternatives that do not conform to this model. It will be argued that this process of agenda-setting can be understood in social constructionist terms as the creation of a 'symbolic universe', an all-

\footnotetext{
${ }^{2}$ S. Tombs and D. Whyte, 'Transcending the Deregulation Debate? Regulation, Risk, and the Enforcement of Health and Safety Law in the UK' (2013) 7 Regulation \& Governance 61.

${ }^{3}$ Reflected in the title of the Government's Young Review: Common Sense, Common Safety (2010).
} 
encompassing body of meaning and common-sense reality, around the issue. ${ }^{4}$ On this reading, the conditions of a dominant (self-)regulatory paradigm have come to be accepted as part of the background against which policymaking occurs, internalising a set of fundamental assumptions that narrow the range of possibilities that regulation can pursue.

This paper sets out the different stages through which this process of social construction has occurred. It shows how, via experimentation, interaction, institutionalization, and internalization, a particular vision of regulation has been advanced. This has been achieved via the adoption of principles of deliberative regulation as a means of bringing external considerations into the policymaking process and populating the regulatory landscape with language and ideas (such as regulatory myths) ${ }^{5}$ that reframe core debates to reflect what are assumed to be widely-held 'common-sense' views of regulation. While the notion of basing legitimate policymaking on deliberative input from external stakeholders is widely-accepted as a principle of 'good government', it is also vulnerable to distortion when consultation is undertaken without safeguarding the validity of the input gathered. This paper shows that this linking of regulatory policy, government ideology, and 'public preference', has resulted in the entrenchment, rather than the offsetting, of a particular, detrimental, agenda for the future of health and safety regulation.

\section{THE REGULATORY CONTEXT: A CHANGING PARADIGM?}

A wealth of policy changes, reviews, and reforms have taken place within the field of health and safety regulation since 2010, and most of these developments have been characterised by a common preoccupation with a particular conception of 'social concern' about health and safety regulation. These developments have taken place against the backdrop of more than

\footnotetext{
${ }^{4}$ P.L. Berger and T. Luckmann, The Social Construction of Reality (1967), 33; 113.

${ }^{5}$ P. Almond, 'The Dangers of Hanging Baskets: Regulatory Myths' and Media Representations of Health and Safety Regulation’ (2009) 36 J. Law \& Society 352.
} 
fifteen years of government review, reform, and debate about the form and function of the regulatory system. For example, the introduction of Regulatory Impact Assessments and the Better Regulation Executive in $1998-99^{6}$ placed procedural controls on the decision-making processes of regulators, and the Hampton and Macrory reviews of $2005-6^{7}$ promoted a view of regulation as a risk-based process of compliance-seeking, using targeted interventions on the basis of focused risk evaluations so as to pursue desired regulatory outcomes in a less burdensome manner. ${ }^{8}$ These two reviews (commissioned by HM Treasury and the Cabinet Office respectively) looked at regulatory practices, not just in the sphere of health and safety, but across all national and local regulators that hold inspection and enforcement functions, with the explicit aim of promoting systems of oversight that were more compatible with the maintenance of business efficiency, flexibility, and economic competitiveness. This burden reduction focused on cutting proactive regulatory inspections by one-third, and limiting the use of criminal prosecution to a smaller number of cases involving a few 'bad apples'.

On one level, the Hampton and Macrory vision fitted well with what the HSE (Health and Safety Executive, the UK's safety regulator) was already doing, ${ }^{9}$ and also reflected existing practices in other regulatory jurisdictions and domains, thereby suggesting a high degree of continuity in the overarching approach and rationality of the regulatory system. ${ }^{10}$ This view of regulatory offending as exceptional, and of wide-ranging intervention as an inefficient use of resources, reflects many of the assumptions found within Ayres and Braithwaite's

\footnotetext{
${ }^{6}$ R. Baldwin, 'Is Better Regulation Smarter Regulation?', (2005) Public Law 485; J. Black, 'The Emergence of Risk-Based Regulation and the New Public Risk Management in the United Kingdom', (2005) Public Law 512. ${ }^{7}$ P. Hampton, Reducing Administrative Burdens: Effective Inspection and Enforcement [The Hampton Review] (2005); R. Macrory, Regulatory Justice: Sanctioning in a Post-Hampton World [The Macrory Review] (2006).

${ }^{8}$ Black, op.cit.n.6; Hampton, id., 20; Macrory, id., 12.

${ }^{9}$ Hampton, op.cit.n.7, 27; K. Hawkins, Law as Last Resort: Prosecution Decision-Making in a Regulatory Agency (2002); B. Hutter, Compliance: Regulation and Environment (1997).

${ }^{10}$ Baldwin, op.cit.n.6; Black, op.cit.n.6; J. Braithwaite, Regulatory Capitalism: How it Works, Ideas for making it Work Better (2008); K. Hawkins, Environment and Enforcement: Regulation and the Social Definition of Pollution (1984); Hutter, id.; D. Levi-Faur, 'The Global Diffusion of Regulatory Capitalism', (2005) 598 Annals of Am. Academy of Political \& Social Science 12.
} 
regulatory pyramid model, an influential reading of the regulatory landscape in which interventions are explicitly weighed against competing economic and public interests. ${ }^{11}$ The preference of the Labour Government of the period 1997-2010 for "risk-tolerant deregulation",12 in the health and safety sphere led to significant reductions in HSE's resourcing, with a decline in rates of inspection from 75,272 in $1999 / 2000$ to 23,004 in 2008/9 as the regulatory regime became more targeted, which included a post-Hampton drop of 50 per cent between $2004-7 .{ }^{13}$ Relatedly, rates of enforcement action also fell during this period; the emphasis on the need to remove "burdens from business" "14 meant that reform was explicitly linked to the reduction of the state's substantive commitments as a regulator, leading to a renewed emphasis upon private and market-based regulatory provision. ${ }^{15}$

At the same time, however, this new risk-based paradigm has had to coexist uneasily with many of the longstanding features and assumptions of the British health and safety regime. Since its inception in modern form, via the Robens Report of $1972^{16}$ and the subsequent Health and Safety at Work Act 1974, the principles of proportional, risk-based self-regulation have gone hand-in-hand with a commitment to generality and breadth of scope, universalism and inclusiveness of application, the pursuit of minimum standards, and a collaborative, consensual approach to regulation. ${ }^{17}$ The new laws were to embed a basic level of attainment and involvement in health and safety management across all British workplaces, thereby

\footnotetext{
${ }^{11}$ I. Ayres and J. Braithwaite, Responsive Regulation: Transcending the Deregulation Debate (1992); P. Mascini 'Why was the Enforcement Pyramid so Influential? And What Price was Paid? (2013) 7 Regulation \& Governance 48; Tombs and Whyte, op.cit.n.2.

${ }^{12}$ A. Dodds, 'The Core Executive's Approach to Regulation: From 'Better Regulation' to 'Risk-Tolerant Deregulation" (2006) 40 Social Policy \& Administration 526; also S. Tombs and D. Whyte, 'A Deadly Consensus: Worker Safety and Regulatory Degradation under New Labour' (2010) 50 Brit. J. Criminology 46.

${ }^{13}$ TUC [Trades Union Congress], The Case for Health and Safety (2010), $<$ http://www.tuc.org.uk/workplace/tuc-18421-f0.pdf>; BRE [Great Britain, Better Regulation Executive], Effective Inspection and Enforcement: Implementing the Hampton Vision in the Health and Safety Executive (2008), <http://www.nao.org.uk/wp-content/uploads/2008/03/HSE_Hampton_report.pdf>, 22.

${ }^{14}$ Hampton, op.cit.n.8.

${ }^{15}$ Dodds, op.cit.n.12; P. James, S. Tombs, and D. Whyte, 'An Independent Review of British Health and Safety Regulation? From Common Sense to Non-sense', (2013) 34 Policy Studies 36; Tombs and Whyte, op.cit.n.12.

${ }^{16}$ Lord Robens, Safety and Health at Work: Report of the Committee 1970-72 (1972) [The Robens Report].

${ }^{17}$ Hawkins, op.cit.n.9; Hutter, op.cit.n.9.
} 
raising expectations and increasing the profile of the issue. And while Robens envisaged that the targeting of resources would be important, this reflected a desire to spread the benefits of regulation as far as possible, and to greatest effect, rather than an ingrained rejection of the notion of regulation. ${ }^{18}$ Before more recent iterations of the risk-based regulatory paradigm recast interventionism and enforcement as signs of inefficiency and unreasonableness, they were widely regarded as reflecting the virtues of proactivity and the capacity of regulators to manage relations with duty-holders. ${ }^{19}$

It must be acknowledged that health and safety regulation has never been applied with the fullness and degree of proactivity that the Robens ideal might suggest, and that there has been much continuity in the way that it has been addressed by successive governments over the last forty years. ${ }^{20}$ And yet it is possible to detect a degree of 'newness' in the approaches of politicians, policymakers, and the media to health and safety in recent years: more critical, and more often on a normative, not just empirical level; more focused on the relationship between the regulatory framework and the wider social world; and more open to airing these criticisms in public. ${ }^{21}$ As Hampton and Macrory demonstrated, there has also been a renewed emphasis on the toleration of risk as a principle of good government; whereas in the past, the creation of areas of deregulated risk was a side-effect of an ideological commitment to a smaller state apparatus, it is now viewed as valuable in itself to allow those areas of risk to exist, and to be managed by individual agents rather than curtailed outright. ${ }^{22}$ Risk-taking is lauded (with, as in the case of the 2008 financial crash, sometimes disastrous consequences)

\footnotetext{
${ }^{18}$ Robens, op.cit.n 16, 66-7.

${ }^{19}$ B. Hutter, 'An Inspector Calls: The Importance of Proactive Enforcement in the Regulatory Context', (1986) 26 Brit. J. Criminology 114.

${ }^{20}$ James et al., op.cit.n.15, 37-8; also M. Beck and C. Woolfson, 'The Regulation of Health and Safety in Britain: From Old Labour to New Labour' (2000) 31 Industrial Relations J. 35; P. Bain, 'Human Resource Malpractice: The Deregulation of Health and Safety at Work in the USA and Britain' (1997) 28 Industrial Relations J. 176; Tombs and Whyte, op.cit.n.12.

${ }^{21}$ Almond, op.cit.n.5; Dodds, op.cit.n.12: 534-6.

${ }^{22}$ Dodds, id.
} 
and the notion of the private sphere as somewhere that government (and hence regulators) should not tread. The outcome of this shift has been the reconceptualisation of regulation as "a second-best choice for social organization" and "an always regrettable means of correcting market failure", ${ }^{23}$ something that is considered illegitimate and undesirable by the public and policymakers alike. This notion of regulation as logically bounded and undesirable in certain fields of human endeavour is culturally as well as formally recognised, and is now the prevailing social narrative around health and safety regulation. ${ }^{24}$ It has also formed a key component of policy rhetoric around the retrenchment of the regulatory framework, both via the Hampton/Macrory agenda, and via subsequent government initiatives since 2010.

\section{FRAMING A SYMBOLIC UNIVERSE OF 'COMMON SENSE'}

How has this new vision of regulation come to exert the influence over policy that it now wields, and why is the notion of regulation as illegitimate in relation to certain areas of risk and activity so ubiquitous? One way of understanding this process is as an example of 'consensus mobilization', or 'framing', as a form of social meaning creation. ${ }^{25}$ Framing involves the generation of an interpretive schema to define a problem by "select[ing] some aspects of a perceived reality and mak[ing] them more salient". ${ }^{26}$ In this way, a social reality is constructed which works to shape subsequent interpretation of that particular issue. While the majority of work around framing has looked at these processes within either social movements or media agendas, the study of wider cultural processes (such as the emergence of a new understanding of health and safety) leads onto discussion of more expansive notions

\footnotetext{
${ }^{23}$ T. Prosser, The Regulatory Enterprise: Government, Regulation, and Legitimacy (2010), 1.

${ }^{24}$ Almond, op.cit.n.5.

${ }^{25}$ R.D. Benford and D.A. Snow 'Framing Processes and Social Movements: An Overview and Assessment' (2000) 26 Annual Rev. Sociology 611; R.M. Entmann 'Framing: Toward Clarification of a Fractured Paradigm' (1993) 43 Journal of Communication 51; E. Goffmann, Frame Analysis: An Essay on the Organisation of the Experience (1974); D. Kahneman and A. Tversky 'Choice, Values, and Frames', (1984) 39 Am. Psychologist 341.

${ }^{26}$ Entmann, id., 52.
} 
of social constructionism. This term connotes a view of social reality as the manufactured outcome of social processes of subjective interpretation and objective sharing of meaning. These shared meanings constitute a commonly-understood and experienced social reality which is taken-for-granted by the participants in it. $^{27}$ The construction of these cultural meanings is an ongoing, dynamic process involving conversation, debate, and testing, in order to ensure that they convincingly explain experienced reality.

A crucial role in the development of a socially constructed reality is played by widelyaccepted 'common-sense' knowledge forms, pragmatic explanatory schemes that contribute to the social construction of a "world of everyday life...taken for granted as reality". 28 These knowledge forms, such as proverbs, moral maxims, and legends, give cohesive meaning to disparate institutional practices and turn latent, easily understood examples of reality into a coherent whole. As it becomes objectively formalised, this explanatory scheme becomes a "symbolic universe", legitimating existing institutions and setting the agenda for, and limits of what is possible through, the exercise of power, which must occur within the scope of that universe. ${ }^{29}$ Four crucial stages have been identified in this process, and together, they provide a useful framework for understanding how recent government reforms have reshaped the social reality of what 'health and safety' means, on both a policymaking and public level. ${ }^{30}$ The first stage, 'experimentation', involves individual sense-making, as a specific perception of a particular situation or experience is developed based on first-hand exposure to it. The social phenomena thus experienced are transformed into a tentative, developmental, understanding of reality, which is subjectively meaningful only for those who hold it. Within

\footnotetext{
${ }^{27}$ Berger and Luckmann, op.cit.n.4; V. Burr, Social Constructionism (2003, $2^{\text {nd }}$ ed.);

${ }^{28}$ Berger and Luckmann, id., 31, 110-115.

${ }^{29}$ S. Lukes, Power: A Radical View (1974).

${ }^{30}$ Berger and Luckmann, op.cit.n. 4, 33-38. These stages are explicated by H. Blaszin and F. Guldenmund, 'The Social Construction of Safety: Comparing Three Realities', (2015) 71 Safety Science 16, in relation to the emergence and development of notions of safety culture, particularly as a notion of "the way we do things around here"; 18.
} 
the regulatory context, this involves the emergence of new narratives within public, media, and official debate about what health and safety signifies.

The second stage, 'interaction', involves the "objectivation" of these subjective meanings as they are given concrete and external significance via their expression in the world of interpersonal communication. ${ }^{31}$ Discussion, debate, and agreement aggregate individual subjective perceptions into a shared objective reality of norms and common sense. In this way, understandings of reality which are individually meaningful are collectivised into mutually meaningful norms. As the next section of this paper explains, processes of deliberative regulation ${ }^{32}$ facilitate the creation of shared understandings about regulation and their externalisation via consultative and policymaking forums. The third component of Berger and Luckmann's model is 'institutionalization', where these aggregated perceptions are established more formally as a component of institutional norms, behaviours, and expectations. Socially generated understandings are officially recognised and objectified as components of "organizational [societal] consciousness", 33 In regulatory terms, this involves formalisation via official, expert scientific discussion and evaluation, and the subsequent creation of policy that reflects these understandings.

The final stage of the process is 'internalization', or the acceptance of formalized norms, standards, and expectations as basic assumptions, or as 'common sense'. The understandings generated become external, objective social reality, shaping perceptions and acting as a limit on the range of possibilities that can be pursued through future decision-making. New

\footnotetext{
${ }^{31}$ Berger and Luckmann, id., 49-51; Blaszin and Guldenmund, id., 18.

${ }^{32}$ See, for example, M. Aalders and T. Wilthagen, 'Moving Beyond Command-And-Control: Reflexivity in the Regulation of Occupational Health and Safety and the Environment' (1997) 19 Law \& Policy 415; Black, 'Proceduralizing Regulation: Part I' (2000) 20 Oxford J. Legal Studies 597; J. Black, 'Proceduralizing Regulation: Part II' (2001) 21 Oxford J. Legal Studies 33; C. Parker, The Open Corporation: Effective SelfRegulation and Democracy (2002); G. Teubner, 'Substantive and Reflexive Elements in Modern Law' (1983) 17 Law \& Society Rev. 239; G. Teubner, 'Juridification: Concepts, Aspects, Limits, Solutions' in A Reader on Regulation, eds. R. Baldwin, C. Scott, and C. Hood (1998) 389.

${ }^{33}$ Berger and Luckmann, op.cit.n.4, 35-6; Blaszin and Guldenmund, op.cit.n.30, 18.
} 
members are socialised into this way of seeing so that their "natural attitude to this world corresponds to the natural attitude of others" and they "share a common sense about its reality" ${ }^{34}$ This notion of common sense, as shared knowledge embedded in self-evident routines of everyday life, is centrally important to the creation of symbolic universes. As Geertz reminds us, however, 'common sense' is a constructed cultural system which reflects conscious determinations about its value as an explanatory schema. ${ }^{35}$ Decisions about what constitutes common sense are value-loaded and reflect one particular way of viewing the world - everything is what it is, practicality is important, and expertise is not. The idea of 'common sense' is central to the Coalition Government's thinking on health and safety regulation, and has been cited as a fundamental value that regulation should aspire to. The intertwining of health and safety and common sense is not new, ${ }^{36}$ but recent developments have explicitly used the idea of common sense as a restrictive and critical limit on regulation; policymakers have endeavoured to engage with representations of public common sense, and use the interaction stages of the meaning-generation process to form and consolidate one particular world-view. As such, it is necessary to consider the relationship between regulatory policymaking and public deliberation and opinion-formation in more detail.

\section{THE NOTION OF DELIBERATIVE REGULATION}

The concept of deliberative regulation draws on democratic social theory (including the work of Jürgen Habermas) ${ }^{37}$ to posit a model of regulation as a forum within which institutional

\footnotetext{
${ }^{34}$ Berger and Luckmann, id., 37, also 149; Blaszin and Guldenmund, id., 18.

${ }^{35}$ C. Geertz, 'Common Sense as a Cultural System', (1975) 33 The Antioch Review 5, 8.

${ }^{36}$ The Robens Report was described as "laced with that massive common sense which only Lord Robens can dispense”: R.C. Browne, 'Safety and Health at Work: The Robens Report', (1973) 30 Brit. J. Occupational Medicine 87.

${ }^{37}$ J. Habermas, Between Facts and Norms [Faktizitat und Geltung], Trans. W. Rehg (1992); The Theory of Communicative Action Vol. I: Reason and the Rationalization of Society [Theorie des Kommunikativen Handelns, Band I: Handlungsrationalitat und gesellschaftliche Rationalisierung], Trans. T. McCarthy (1984).
} 
outcomes are grounded in participatory public discourses. ${ }^{38}$ By establishing mechanisms to allow for the participation of a range of social actors in the regulatory process, this model seeks to ensure that the outcomes of decision-making are both more responsible, in the sense of taking account of a wider range of interests, and more responsive, in that they reflect public concerns more directly. ${ }^{39}$ In a world where regulatory agencies are increasingly fragmented in structure and function, and faced with regulating an increasingly complex and contested set of risk issues, they are unable to retain a monopoly on 'rightness', and so must seek input from others in order to transcend their own particularism. ${ }^{40}$ On the one hand, this reflects a shift towards responsive law that is instrumental, altering behaviour in pursuit of democratically-expressed public interest goals. $^{41}$ Deliberative engagement provides a responsive means of determining the goals to be pursued via a dispassionate bureaucratic process. ${ }^{42}$ At the same time, it justifies the decisions taken, democratising them and ensuring "the permeability of private organizational systems and social power directly to civil society", 43 acting as a driver of good regulation and breeding corporate virtue. ${ }^{44}$

This recognition of the potential value of deliberative regulatory input has led to the widespread acceptance of such measures as a contemporary norm of 'good governance', ${ }^{45}$

\footnotetext{
${ }^{38}$ See op.cit.n.32 for relevant references.

${ }^{39}$ J. Fishkin, Democracy and Deliberation: New Directions for Democratic Reform (1991); J. Fishkin, When the People Speak: Deliberative Democracy and Public Consultation (2009); A. Gutmann and D. Thompson, Why Deliberative Democracy? (2002); C. Sunstein, Designing Democracy: What Constitutions Do (2001).

${ }^{40}$ Black (2000), op.cit.n.32, 599.

${ }^{41}$ J.R. Gusfield, The Culture of Public Problems: Drinking-Driving and the Symbolic Order (1981); Hawkins, op.cit.n.9, 4; F. Haines, The Paradox of Regulation: What Regulation can Achieve and What it Cannot (2011), 23; P. Nonet and P. Selznick, Law and Society in Transition: Toward Responsive Law (1978).

${ }^{42}$ The administrative orderliness of deliberative processes are identified by L.M. Sanders, 'Against Deliberation' (1997) 25 Political Theory 347, 356.

${ }^{43}$ Parker, op.cit.n.32, p40.

${ }^{44}$ Black (2001), op.cit.n.32; N. Gunningham and J. Rees, 'Industry Self-Regulation: An Institutional Perspective', (1997) 19 Law \& Policy 363; Haines, op.cit.n.41; Parker, op.cit.n.32.

45 J. Bohman, 'The Coming of Age of Deliberative Democracy', (1998) 6 Journal of Political Philosophy 400; J. Bohman, Public Deliberation: Pluralism, Complexity, and Democracy (2000); S. Chambers, 'Deliberative Democratic Theory', (2003) 6 Annual Rev. Political Science 307; Fishkin (2009), op.cit.n.39; Gutmann and Thompson, op.cit.n.39; M.X. Delli Carpini, F. Lomax Cook, and L.R. Jacobs, 'Public Deliberation, Discursive Participation, and Citizen Engagement: A Review of the Empirical Literature', (2004) 7 Annual Rev. Political
} 
preventing perceived democratic deficits from undermining systems of regulation dominated by technical expertise. ${ }^{46}$ Within the UK, notions of deliberative regulation have been harnessed as part of a wider drive towards accountability and an open, flexible, 'nonmajoritarian' state infrastructure. ${ }^{47}$ To these ends, the British Government has undertaken to apply a consultative, deliberative approach to regulation, centred on impact assessment and stakeholder engagement as means of broadening the base of evidence-led decision-making. ${ }^{48}$ In the case of impact assessments, this takes the form of evidence as to the weighting of the positive and negative effects of interventions $;{ }^{49}$ in the case of stakeholder engagement, this involves gathering meaningful input from those affected by reform. Both approaches involve providing policymakers with input that "allow the Government to make informed decisions on matters of policy, to improve the delivery of public services, and to improve the accountability of public bodies". 50

The crucial issue which arises in relation to the notion of deliberative regulatory engagement is one of depth and quality; it is not necessarily the case that any form of public consultation will render a policymaking process 'deliberative'. ${ }^{51}$ As discussed previously, the concept of deliberative regulation is premised upon 'thick' forms of engagement which are participatory,

Science 315; N. Roberts, 'Public Deliberation in an Age of Direct Citizen Participation', (2004) 34 Am. Rev. Public Administration 315.

${ }^{46}$ R.A. Dahl, 'A Democratic Dilemma: System Effectiveness versus Citizen Participation', (1994) 109 Political Science Quarterly 23; S. Solomon and J. Abelson, 'Why and When Should We Use Public Deliberation?', (2012) 42 Hastings Centre Report 17.

${ }^{47}$ D. Levi-Faur, 'The Odyssey of the Regulatory State: From a 'Thin' Monomorphic Concept to a 'Thick' and Polymorphic Concept, (2013) 35 Law \& Policy 29, 35; M. Moran, The British Regulatory State: High Modernism and Hyper Innovation (2003); Prosser, op.cit.n.23, ch.10; op.cit.n.1, 611-2.

${ }^{48}$ BRE, op.cit.n.13; see also The Cabinet Office, Consultation Principles (2012) https://www.gov.uk/government/publications/consultation-principles-guidance; HM Government, The Civil Service Reform Plan (2012), http://resources.civilservice.gov.uk/wp-content/uploads/2012/06/Civil-ServiceReform-Plan-acc-final.pdf, ch.2.

${ }^{49}$ Baldwin, op.cit.n.6; BERR [Great Britain, Department for Business, Enterprise, and Regulatory Reform], Impact Assessment Guidance (n.d.); http://www.berr.gov.uk/files/file44544.pdf.

${ }^{50}$ BRE [Great Britain, Better Regulation Executive], Code of Practice on Consultation (2008): http://www.bis.gov.uk/files/file47158.pdf, 3.

${ }^{51}$ See Delli Carpini et al., op.cit.n.45; Sanders, op.cit.n.42; Solomon and Abelson, op.cit.n.46. 
and which promote consensus and intersubjective understanding. ${ }^{52}$ Policy outcomes are thus legitimised as a form of action taken in the 'public interest', and are embedded within their social contexts and protected from domination by economic and bureaucratic power. ${ }^{53}$ In order to be regarded as truly deliberative, public debate must be rational and truthful, open and inclusive, and ongoing or revisable in nature. ${ }^{54}$ Only under these conditions can processes be said to be sufficiently non-hierarchical, fair, and mutual to allow all participants to transcend their particular standpoint and ensure that attitudes are moderated towards consensus. ${ }^{55}$ For these reasons, deliberative engagement has the capacity to perform a fundamentally important role within the 'interaction' stage of Berger and Luckmann's model, turning subjective perceptions into a shared objective reality. In particular, the emphasis on the mutual adjustment of perceptions at this stage is consistent with the pursuit of intersubjective understanding that deliberative regulatory engagement typically involves.

In practice, the conditions for 'thick' deliberation are structurally and institutionally difficult to achieve because participatory forums that allow for this kind of engagement are so resource-intensive. This approach also assumes a degree of epistemological proximity between parties which may not exist; the views expressed may be too polarised to allow for common understandings to emerge. ${ }^{56}$ Crucially, there is also an assumption that deliberative processes are open to all, whereas in reality different groups are able to access these forums to different degrees, depending on the levels of social and cultural power they possess. ${ }^{57}$ This

\footnotetext{
${ }^{52}$ Habermas (1984), op.cit.n.37; J. Habermas, The Theory of Communicative Action Vol. II: The Critique of Functionalist Reason [Theorie des Kommunikativen Handelns, Band II: Zur Kritik der funktionalistischen Vernunft] Trans. T. McCarthy (1987).

${ }^{53}$ This echoes Polanyi's analysis of the disembedding of self-regulating markets: K. Polanyi, The Great Transformation: The Political and Economic Origins of our Time (1944); also Black (2000), op.cit.n.32, 598.

${ }^{54}$ Habermas (1984), op.cit.n.37, 25-6; Black (2000), op.cit.n.32, 611.

${ }^{55}$ P. Almond, Corporate Manslaughter and Regulatory Reform (2013), 155-6.

${ }^{56}$ Black (2001), op.cit.n.32, 36; A. Fraser, 'A Marx for the Managerial Revolution: Habermas on Law and Democracy', (2001) 28 J. Law \& Society 361.

${ }^{57}$ C.M. Hendriks, 'When the Forum Meets Interest Politics: Strategic Uses of Public Deliberation', (2006) 34 Politics \& Society 571; Sanders, op.cit.n.42, 352-3.
} 
means that requirements which are intended to protect the quality of participation systematically disadvantage those interests which are less able to organise professional representation. Partly as a result of these problems, many attempts to implement mechanisms of deliberative engagement reflect what may be described as 'thin' rather than 'thick' versions of this approach. ${ }^{58}$ Whereas thick conceptions reflect the mutual features of deliberative discourse, thin versions retain a commitment to the hierarchical development of regulatory goals which are then subjected to democratic approval. The policy-making process is pluralistic, with different interest groups having input via (for example) the submission of evidence or participation in a discussion forum. This ensures that outcomes reflect the aggregation of preferences, but not necessarily formal participation in policy-creation. Instead, the emphasis is on good-quality, rather than substantively fair, regulation, subjecting bureaucratic decision-making to public scrutiny. ${ }^{59}$

This is the kind of stakeholder engagement solicited by the UK government, where the emphasis has been placed upon plurality rather than consensus; the goal is the representation of competing interests and there is no undertaking to actually use the information gathered. This model reflects a restricted liberal view of the state's role as an arbiter of conflicts between individual interests, ${ }^{60}$ something which is both empirically questionable ${ }^{61}$ and also open to distortion, as decision-making processes centred on bargaining may be dominated by vested interests, whose capacity to organise their representative resources is greatest, leading to partisanship, instrumentalism, and regulatory capture. ${ }^{62}$ Thin deliberative processes tend to be narrowly-drawn, meaning that they reflect a predetermined range of outcomes and so

\footnotetext{
${ }^{58}$ Black (2000), op.cit.n.32, 607.

${ }^{59}$ It should not be assumed that thin versions of proceduralization retain a commitment to expertise and goodquality regulation while thicker versions do not; the latter views rigorous and reciprocal deliberative input as a guarantee of, and not an alternative to, substantively sound policymaking: Almond, op.cit.n.55, 155-6.

${ }^{60}$ R.A. Dahl, Who Governs? Democracy and Power in an American City, (1961).

${ }^{61}$ G.W. Domhoff, Who Really Rules? New Haven and Community Power Re-examined, (1978).

${ }^{62}$ Almond, op.cit.n.55, ch.3; Haines, op.cit.n.41; Hendriks, op.cit.n.57.
} 
empower those who set the agenda. ${ }^{63}$ They are also not truly deliberative, since the preferences of actors exist a priori and are not mediated by deliberative participation, remaining the same at the end of the process as they were at that start. ${ }^{64}$ Political risk management is thus dominated by an agenda that tends towards the superficial, and which involves only one, limited, version of public attitudes.

Together, these objections illustrate that 'thin' deliberation centres on the gathering of preferences as input into policy processes, rather than the generation of outputs that reflect deeper citizen engagement. This focus on input rather than output is central to the approach to public consultation taken by the UK government in recent years, perhaps reflecting the British regulatory state's deep-seated institutional inclination towards top-down, centralised bureaucratic policy-making, which efforts at 'modernization from above' have not dimmed. ${ }^{65}$ Government practice has been driven by concern over the unresponsiveness of regulatory systems to the external social needs they should fulfil, and while 'thin' deliberative processes construct the appearance of responsiveness, using them to tackle this problem exposes their fragility. These fragilities are especially pronounced in policy areas which are contested by populist social agendas, and indeed, thinly deliberative processes may be utilised precisely in order to allow these agendas to permeate the policymaking process. ${ }^{66}$ When political actors identify latent movements that are sympathetic to their ideological preferences, but which lack the formalised rigour required by mechanisms of evidence-based policy engagement, ${ }^{67}$ public engagement may be employed as a means of imbuing notionally objective processes with this particular political agenda. Expert evidence is thus weighed against a conception of

\footnotetext{
${ }^{63}$ P. Bachrach and M.S. Baratz, (1962) 'Two Faces of Power', (1962) 56 Am. Political Sciences Rev. 947; Hendriks, id.; Lukes, op.cit.n.29.

${ }^{64}$ Black (2001), op.cit.n.32, 607.

${ }^{65}$ Moran, op.cit.n.47; Levi-Faur, op.cit.n.47, 36.

${ }^{66}$ Hendriks, op.cit.n.57, 581-2.

${ }^{67}$ I. Sanderson, 'Evaluation, Policy Learning, and Evidence-Based Policymaking', (2002) 80 Public Administration 1; M. Kogan 'The Impact of Research on Policy' in Speaking Truth to Power: Research and Policy in Lifelong Learning, ed. F. Coffield (1999) 11; Sunstein, op.cit.n.39.
} 
'public concern' which is objectivised as an alternative form of 'evidence' via deliberative engagement. This process has been reflected in the UK's ongoing health and safety reforms since 2010, where thin deliberation has been used to embed an ideological, populist view of health and safety at work regulation within a policymaking process that can be mapped across the four stages (experimentation, interaction, institutionalization, internalization) of Berger and Luckmann's model of social reality construction.

\section{EXPERIMENTATION: NEW GOVERNMENT, NEW RHETORIC}

The reshaping of regulatory capacity prior to 2010 was driven by the strategic framing of regulatory compliance in rationalistic terms, something which was arguably constructed mutually by business duty-holders and governmental actors, ${ }^{68}$ and which provided a basis for the subsequent development of a wider account of regulation and its social role. This account has underpinned the extension of those beliefs beyond issues of intervention and into other areas of regulatory policy, including the boundaries of the regulatory framework itself. ${ }^{69} \mathrm{~A}$ powerful public narrative of 'health and safety gone mad', a resistance to regulation fuelled by hostile media coverage which documents examples of regulatory unreasonableness, heavy-handedness, and excess, has risen to prominence during the last fifteen years or so. ${ }^{70}$ Stories about children being forced to wear safety goggles to play conkers, or about any number of other situations in which regulators are alleged to have stepped into the realm of absurdity, are a commonplace and recurring feature of media debate. These 'regulatory myth'

\footnotetext{
${ }^{68}$ L.B. Edelman, C. Uggen, and H.S. Erlanger, 'The Endogeneity of Legal Regulation: Grievance Procedures as Rational Myth', (1999) 105 Am. J. Sociology 406; L.B. Edelman and S.A. Talesh, 'To Comply or Not to Comply-That Isn't the Question: How Organizations Construct the Meaning of Compliance', in Explaining Compliance: Business Responses to Regulation, eds. C. Parker and V.L. Nielsen (2011), 103; S. Gilad, 'Beyond Endogeneity: How Firms and Regulators Co-Construct the Meaning of Regulation', (2014) 36 Law \& Policy 134.

${ }^{69}$ Edelman et al., ibid., 411.

${ }^{70}$ Almond, op.cit.n.5; D. Ball and L. Ball-King, 'Safety Management and Public Spaces: Restoring Balance', (2013) 33 Risk Analysis 763; S. Lloyd-Bostock, 'Public Perceptions of Risk and 'Compensation Culture' in the UK', in Anticipating Risks and Organising Risk Regulation, ed. B. Hutter (2010), 90; K. Williams, 'Politics, the Media and Refining the Notion of Fault: Section 1 of the Compensation Act 2006', (2006) 4 J. Personal Injury Law 347.
} 
stories coalesce around a set of well-established core themes, such as a challenge to some form of traditional activity and the use of humour to critique regulators, but they also retain a degree of non-specificity which renders them hard to definitively disprove. Like other compelling story forms, ${ }^{71}$ this mixture has ensured their prominence within public discourse.

But as well as being popular, regulatory myth stories are also political phenomena, in that they challenge the legitimacy of regulators and are indicative of a principled objection to the bureaucratic over-reaching of the state and the risk-aversion of modern society. ${ }^{72}$ Their core messages about the unreasonableness of state-imposed external constraints on the freedoms of private economic actors to determine the appropriate balance of risk and reward also reflect the fundamental principles of a neo-liberal approach to regulation. ${ }^{73}$ Regulatory myths form part of a political dialogue about the undesirability of regulatory burdens and, despite the efforts of HSE to publicly rebut these stories, ${ }^{74}$ by the mid-2000s, it was clear that they were increasingly being drawn upon to support influential currents within political thought and ideology. ${ }^{75}$ While in opposition, David Cameron cited a number of regulatory myths when criticising a "health and safety...culture [which] has infected every part of our life", ${ }^{76}$ and stating that " $[W]$ hen children are made to wear goggles by their headteacher to play conkers... what began as a noble intention to protect people from harm has mutated into a

\footnotetext{
${ }^{71}$ C. Heath, C. Bell, and E. Sternberg, 'Emotional Selection in Memes: The Case of Urban Legends', (2001) 81 J. Personality \& Social Psychology 1028.

${ }^{72}$ Almond, op.cit.n.5; Ball and Ball-King, op.cit.n.70; F. Furedi, Culture of Fear: Risk-Taking and the Morality of Low Expectation (1997); A. Giddens, Modernity and Self Identity: Self and Society in the Late Modern Age (1991).

${ }^{73}$ G.C. Gray, 'The Responsibilization Strategy of Health and Safety: Neo-liberalism and the Reconfiguration of Individual Responsibility for Risk', (2009) 49 Brit. J. Criminology 326; S.S. Silbey, 'Taming Prometheus: Talk About Safety Culture', (2009) 35 Ann. Rev. Sociology 341; Tombs and Whyte (2010), op.cit.n.12.

${ }^{74}$ HSE's Sensible Risk Management policy instigated a proactive campaign of media engagement to try and challenge regulatory myths; HSE [Great Britain, Health and Safety Executive], Sensible Risk Management: HSE Board Paper HSE/06/46 (2006). See also the stories contained at <http://www.hse.gov.uk/myth/index.htm $>$.

${ }^{75}$ An influential policy paper by the Policy Exchange think-tank (C. Taylor, Health and Safety: Reducing the Burden (2010), <http://www.policyexchange.org.uk/publications/category/item/health-and-safety-reducing-theburden>), published just before the 2010 General Election, drew heavily on regulatory myths and other critical claims when setting out a deregulatory reform agenda. Lord Young, who wrote the foreword for this paper, would go on to echo and implement much of its content via his review (op.cit.n.3) once in government.

${ }^{76}$ Speech to the Conservative Party Conference, 01/10/2008; reported by The Guardian, <http://www.guardian.co.uk/politics/2008/oct/01/davidcameron.toryconference1>.
} 
stultifying blanket of bureaucracy". ${ }^{77}$ Once in power after the 2010 election, his Government set out to roll back the state and tackle safety laws which had "encroached into various different parts of national life [by, for instance]...stopping Bonfire Night...", 78 invoking regulatory myths to frame the idea of deregulation as in the public interest. The 2010 election manifesto of the Conservative Party, the dominant partners in the coalition Government, undertook to reduce the amount of regulation and red tape that applied to business, and (referencing one key strand of regulatory myth story) amend "health and safety laws that get in the way of common sense policing", 79

From the outset, then, the ambition to reform and restrict the scope of the existing health and safety laws was present within the Government's policy agenda. But this particular, individual commitment was only meaningful for those who were similarly committed to a small-state political agenda; a degree of experimentation was required in order to render it both coherent and accessible to a wider audience. As such, the linkage of this commitment to the wider cultural tropes contained within regulatory myth stories constituted an experimental attempt to develop a new understanding of the reality of regulation, one which links wider processes of individual sense-making about visible phenomena (myth stories) to an overarching explanatory framework of ideas (about deregulation). This ‘bottom-up' approach to the creation of meaning via practical experience and first-hand exposure is a common feature of many contexts within which understandings of health and safety are generated, particularly given the relatively low levels of latent knowledge about broader health and

\footnotetext{
${ }^{77}$ Speech to Policy Exchange, 01/12/2009; BBC News <http://news.bbc.co.uk/1/hi/uk_politics/8388025.stm>. The 'goggles for conkers' story is probably the best-known myth about health and safety in the UK: Almond, op.cit.n.5.

${ }^{78}$ D. Martin, 'Bonfire of elf 'n' safety: Cameron plans to tear up regulations which 'have become a music hall joke', Daily Mail, 20 October 2010 <http://www.dailymail.co.uk/news/article-1313432/David-Cameron-planstear-mad-health-safety-regulations.html\#ixzz2NWonwwj2>.

${ }^{79}$ Conservative Party, Invitation to Join the Government Of Britain: The Conservative Manifesto (2010), 20, 57 $<$ https://www.conservatives.com/ /media/files/activist\%20centre/press $\% 20$ and\%20policy/manifestos/manifesto 2010>.
} 
safety regulation, and practice. ${ }^{80} \mathrm{~A}$ social narrative already existed around this area of regulation, but a process of experimentation with meaning allowed for that narrative to be appropriated as a core feature of future policy, forging an understanding of restrictive unreasonableness, red tape, and regulation as an area of policy that interferes with individual self-determination, as interrelated concepts which cumulatively provide a clear sense-making framework for use in this area.

\section{INTERACTION: THE YOUNG REVIEW AND THE 'RED TAPE CHALLENGE'}

In June 2010, just a few weeks after its election, the coalition Government launched a formal review of health and safety regulation. Lord Young of Graffham, a Conservative peer, was commissioned to report on 'the rise of the compensation culture over the last decade coupled with the current low standing that health and safety legislation now enjoys, ${ }^{81}$ and quickly made clear his guiding assumptions: "We have decided to apply [health and safety] across all parts of life, which is a nonsense...It has become a music hall joke...My job is to put commonsense back in and deregulate it". ${ }^{82}$ The terms of reference and scope of the report were both clearly influenced by the experimental sense-making agenda around health and safety that had previously been constructed, as well as a similar narrative about a 'compensation culture'. ${ }^{83}$ The Review was happy to accept from the outset that health and safety law had suffered a collapse of public legitimacy as a result of its over-reaching tendencies, ${ }^{84}$ and that the scope of health and safety regulation must necessarily be bounded

\footnotetext{
${ }^{80}$ Blaszin and Guldenmund, op.cit.n.30, 25; P. Almond and S. Colover, 'Mediating Punitiveness: Understanding Public Attitudes Towards Work-Related Fatality Cases', 7 European J. Criminology 323.

${ }^{81}$ Young, op.cit.n.3, terms of reference.

${ }^{82}$ C. Hope, 'Health and safety rules should be removed from offices, says David Cameron adviser', Telegraph, 14 June $2010<$ http://www.telegraph.co.uk/news/politics/7826183/Health-and-safety-rules-should-be-removedfrom-offices-says-David-Cameron-adviser.html $>$.

${ }^{83}$ J. Hand, 'The Compensation Culture: Cliché or Cause for Concern?', (2010) 37 J. Law \& Society 569; A. Morris, 'Spiralling or Stabilising? The Compensation Culture and Our Propensity to Claim Damages for Personal Injury', (2007) 70 Modern Law Rev. 349; K. Williams, 'State of Fear: Britain's 'Compensation Culture' Revisited', (2005) 25 Legal Studies 500.

${ }^{84}$ Young, op.cit.n.3, 11.
} 
by the need to avoid compromising the economic interests of business. ${ }^{85}$ The excessive costs of health and safety compliance were evidenced by reference to regulatory myths, making the interplay between perception and practice central to the subsequent Review.

Young made a series of recommendations relating to the 'compensation culture', centred on the streamlining of the civil litigation system and the regulation of claims management companies. $^{86}$ In relation to health and safety, he recommended reducing the requirements incumbent upon low-hazard workplaces and simplifying the legislative framework in order to return to the principles of proportionality underpinning the Health and Safety at Work Act 1974. ${ }^{87}$ In doing so, Young voiced principles which were well-established within regulatory circles, ${ }^{88}$ but the detail of these proposals was not concrete; what is regarded as a 'low-risk' workplace is unclear, as are the meanings of 'simplification' and 'exemption'. The report also recommended the removal of restrictions upon good Samaritans, adventure sports, school trips, and children's play areas, ${ }^{89}$ and the creation of an Ombudsman to allow individuals to challenge unreasonable safety decisions. Perhaps the most striking feature of the Young Review was the extent to which it explicitly linked these concrete issues of policymaking to the experimental sense-making account of health and safety outlined in the previous section, conflating perceptions and substantive realities as a result; it concluded that the compensation culture was an issue of "perception rather than reality", 90 but proposed substantive reforms to the law in order to tackle this perceived problem. And in relation to health and safety law,

\footnotetext{
${ }^{85}$ The Review's preamble and introduction make repeated references to "bureaucratic burdens", "costly burdens for businesses", "costly...risk assessments", and "fear among business owners of having to pay out"; ibid., 7-11.

${ }^{86}$ See A. Morris, “Common Sense Common Safety': The Compensation Culture Perspective', (2011) 27 Professional Negligence 82, for a review.

${ }^{87}$ Young, op.cit.n.3, 28.

${ }^{88}$ Black, op.cit.n.6; J. Black and R. Baldwin, 'Really Responsive Risk-Based Regulation', (2010) 32 Law \& Policy 181; Hampton, op.cit.n.7; B.M. Hutter, 'Understanding the new Regulatory Governance: Business Perspectives', (2011) 33 Law \& Policy 459.

${ }^{89}$ All recur in regulatory myth stories: Almond, op.cit.n.5.

${ }^{90}$ Young, op.cit.n.3, 19.
} 
it recognised that many of the stories that underpin that sense-making account of regulation are misperceptions, driven by a media agenda, ${ }^{91}$ but also accepted the content of those misperceptions as a basis for decision-making.

The Review undertook interaction with a wider public constituency via two mechanisms: a consultation process which gathered responses from stakeholders, and an engagement with mediated popular opinion via the regulatory myths that were cited, neither of which made any claims as to deliberative breadth. The former involved a relatively low-key engagement with businesses, interest groups, representative organisations, trades unions, and self-selecting individuals who responded to an invitation to comment; this was translated by Young into a self-contained series of observations, mostly about the problem of negative media coverage, but a few of which identified a lack of regulatory clarity and the problems of over-burdening businesses. $^{92}$ The latter was a means of engaging with public concern by proxy, treating adverse media commentary as both a problematic phenomenon, and as an indicator of a popular mandate for change. Reform was thus required because "many are the reports of activities and events banned...in the name of health and safety", 93 which highlighted a system gone wrong. Crucially, this step allowed for the development of an emergent, shared understanding around this issue, recasting otherwise technical, obscure issues of regulatory policy via the medium of easily-accessible, public narratives of 'health and safety gone mad', using the pessimistic outlook of the latter to evidence a need to change the former, and thus binding government ideology and public perception into something approaching a whole.

It must be recognised that the Young Review was a political undertaking. It was conducted by a former Conservative Government Minister who had overseen a previous era of

\footnotetext{
91 id., 25.

92 id., 46-8.

93 id., 26.
} 
deregulatory initiative during the $1980 \mathrm{~s},{ }^{94}$ and was commissioned early during the Coalition Government, seemingly so that the Conservative faction within it could show an ongoing commitment to politically symbolic elements of its election manifesto. As such, it was always likely to be heavily concerned with issues of public perception. Nevertheless, Young's engagement with external input was highly selective and the Report gave more prominence to anecdotal evidence than it did to the evidence provided by the consultation respondents. In a sense, this highlights one of the key problems associated with thinly deliberative processes; the opportunity for input provided is not counterbalanced by a clear commitment to testing the validity of that input through processes of sustained citizen engagement. ${ }^{95}$ By privileging the insights that regulatory myths are claimed to provide (at the same time as decrying their ubiquity), the Young Review both validated them and used them to legitimate its own ideological preferences. The openness of the review process was sufficient to allow for consideration of evidence which was of limited factual veracity and inherently deregulatory in nature, suggesting that the process was designed with just such an outcome in mind. ${ }^{96}$

The Young Review was supported from April 2011 onwards by the 'Red Tape Challenge', conducted by the Cabinet Office. This involved the opening up of government via public consultation as part of a citizen-led "fight back" against red tape, ${ }^{97}$ a shorthand term for an essentially objectionable form of bureaucratically-embedded constraint. ${ }^{98}$ In this sense, the Red Tape Challenge was framed from the outset as a deregulatory process, in accordance

\footnotetext{
${ }^{94}$ HM Government, White Paper: Lifting the Burdens [Cmnd. 9571] (1985); D. Young, The Enterprise Years: A Businessman in the Cabinet (1990), 144-148.

95 Black, op.cit.n.32, 607.

${ }^{96}$ Hendriks, op.cit.n.57; Sanderson, op.cit.n.67.

97 The 'Red Tape Challenge' website is at <http://www.redtapechallenge.cabinetoffice.gov.uk/about/> and the 'Health and Safety Spotlight' is at <http://www.redtapechallenge.cabinetoffice.gov.uk/themehome/health-andsafety-spotlight/>. See also R. Hyde, 'Conversations about Health and Safety Regulation: An analysis of the Red Tape Challenge', (forthcoming); M. Lodge and K. Weigrich, 'Crowdsourcing and regulatory reviews: A new way of challenging red tape in British government?, (forthcoming) Regulation \& Governance, doi:10.1111/rego.12048.

${ }^{98}$ Prosser, op.cit.n.23: 1; A.W. Gouldner, 'Red Tape as a Social Problem', in Reader in Bureaucracy, eds. R.K. Merton et al., (1952), 410; H. Kaufman, Red Tape: Its Origins, Uses and Abuses (1977)
} 
with the emergent Governmental understanding of health and safety regulation as costly, ineffective, and obstructive. This process was significant because of its deliberative component; it sought to harness the power of the internet to elicit the opinions of the public sphere, ${ }^{99}$ and to channel this information into the decision-making process as a representation of democratic preference. This was a public forum, and did not seek to engage with expert opinion or specified stakeholders. As such, it fitted the model of 'thin' and pluralistic public consultation outlined previously. Health and safety was one of the six core themes singled out for attention and attracted 1320 responses, a significant proportion of which were very hostile, citing the economic costs of regulation and the lack of self-reliance that it instilled in individuals. ${ }^{100}$ Many respondents cited examples that were drawn from 'regulatory myth' stories or narratives of tort law excess, which the Red Tape Challenge then reproduced for subsequent consumption by formal government bodies.

The Red Tape Challenge illustrates clearly the 'mutual adjustment of perceptions' that constitutes the second, interaction stage of Berger and Luckmann's model. The input gathered via 'thin' deliberative engagement was limited to surface-level expression of opinion rather than outcomes of any open and ongoing processes of deliberative engagement, ${ }^{101}$ and so did not test the truthfulness of these beliefs, ${ }^{102}$ but rather allowed for them to be shared and reinforced. The rhetorical framing of the process as a Red Tape Challenge' pre-empted its findings and positively invited comments questioning the legitimacy of regulation, and this 'agenda-setting ${ }^{103}$ shaped participants' understandings in accordance with the established ideological narrative that the Government was seeking to

\footnotetext{
${ }^{99}$ L. Dahlberg, 'The Internet and Democratic Discourse: Exploring the Prospects of Online Deliberative Forums Extending the Public Sphere', (2001) 4 Information, Communication \& Society 615.

${ }^{100}$ Hyde, op.cit.n.97, 9-11.

101 id., 16-17; Lodge and Weigrich, op.cit.n. 97.

102 Habermas (1984), op.cit.n.37, 25-6; Black (2000), op.cit.n.32, 611.

${ }^{103}$ Hendriks, op.cit.n.57.
} 
develop. ${ }^{104}$ The conjunction of regulatory myths and a dislike of 'red tape' with a more principled neo-liberal objection to intervention in the private sphere of the workplace was central to this process of consultation, and while particular stories of excess were only occasionally linked to subsequent reform proposals, ${ }^{105}$ their wider impact was to reframe the agenda in terms of a public resistance to health and safety regulation grounded in 'commonsense' ideas that should properly be regarded as natural and beyond debate. ${ }^{106}$ And once these understandings were embedded in a 'comprehensive' survey of public attitudes, and communicated in an authoritative policy document, they became increasingly 'objectivised' as concrete social facts. ${ }^{107}$ Subsequent outcomes would be judged against the supposedly universal, common-sense principles of individualised (rather than mandated) decisionmaking, rationalized (rather than universal) intervention, and business-oriented (rather than welfarist) regulation that this thinly-deliberative process was designed to find support for.

\section{INSTITUTIONALIZATION: THE LÖFSTEDT REVIEW}

The centrepiece of the Government's reform process was Professor Ragnar Löfstedt's review of health and safety. This was commissioned in March 2011 via the Government's 'Good Health and Safety, Good for Everyone' policy document, ${ }^{108}$ which also announced a significant cut to HSE's enforcement regime, including reductions of one-third in the rates of scheduled inspection, particularly of "businesses in lower risk areas". ${ }^{109}$ It also preemptively answered some of the questions that Löfstedt was supposed to address by asserting

\footnotetext{
${ }^{104}$ James et al., op.cit.n.15.

${ }^{105}$ Such as the burden of mandatory annual PAT (portable appliance testing) inspections, a regulatory myth which was highlighted on the Red Tape Challenge website and cited as having led to reform of the regulatory guidance <http://www.redtapechallenge.cabinetoffice.gov.uk/themehome/health-and-safety-spotlight/>. ${ }^{106}$ Geertz, op.cit.n. 35, 18-23.

${ }^{107}$ Berger and Luckmann, op.cit.n.4., 49; Blaszin and Guldenmund, op.cit.n.30., 18.

${ }^{108}$ DWP [Great Britain, Department of Work and Pensions], Good Health and Safety, Good for Everyone (2011) <http://www.dwp.gov.uk/docs/good-health-and-safety.pdf $>$.

${ }^{109}$ id., 8-9. This took place against the backdrop of a 35\% cut to HSE's budget following the Coalition government's spending review.
} 
that the costs of regulation were too high, and "the burden of health and safety red tape [is] too great", pointing to the (by now) objectivised social fact of a "health and safety culture that causes so much frustration in Britain today". ${ }^{110}$ At the same time, it set out the terms of reference of the Löfstedt review, which were to analyse the costs and benefits of health and safety regulation, to investigate the 'gold-plating' of European Union regulations, and to identify "where health and safety regulations have led to unreasonable outcomes". ${ }^{111}$ These terms of reference reflect the common-sense shared understandings and assumptions (things "everyone knows" to be true ${ }^{112}$ ) to have emerged via the preceding interaction stage: topdown rule-imposition leads to unreasonableness and red tape; regulation must be risk-based, proportionate, and targeted at the problematic minority of duty-holders; and the need for business competitiveness demands that regulations be minimalist ${ }^{113}$ and economicallyrational. ${ }^{114}$ Arguably, Löfstedt's own appointment was an act of framing; as a respected researcher who had previously advocated risk-based approaches, but whose background was sufficiently distant from local debates about health and safety regulation, his likely focus on due process would not involve reopening the partisan debates that Young and the Red Tape Challenge had already settled. In a sense, authorial neutrality was a means of ensuring that decisions would be made within the terms of the emergent social reality.

The Löfstedt report was published in November 2011 and made wide-ranging substantive recommendations, including the revocation and amendment of several pieces of obsolete legislation, the consolidation and review of regulations and Approved Codes of Practice, and the simplification of online risk assessment tools, reflecting concerns about the volume and

\footnotetext{
110 id., 3.

${ }^{111}$ DWP [Great Britain, Department of Work and Pensions], The Löfstedt Review: An Independent Review of Health and Safety Legislation - Terms of Reference, (2011) <http://www.dwp.gov.uk/docs/lofstedt-tor.pdf > .

112 Geertz, op.cit.n.35, 25.

113 James et al., op.cit.n.15, 47-8.

${ }^{114}$ R.E. Löfstedt, Reclaiming Health and Safety for All: An Independent Review of Health and Safety Legislation [The Löfstedt Review] (2011), 23-4.
} 
complexity of the law that echo those of the Robens Committee 40 years before. ${ }^{115}$ Overall, though, the report concluded that the existing law was "broadly fit for purpose", and Löfstedt observed that "I have neither seen nor heard any evidence to suggest that there is a case for radically altering or stripping back current health and safety regulation". ${ }^{116}$ The report was less ambiguous than Young when handling regulatory myths, acknowledging that they were problems of perception, inaccurate media constructs which damage the regulatory system, ${ }^{117}$ and which demanded solutions (simplification, targeting, risk communication) that addressed their causes.

Like Young, Löfstedt undertook a consultation process with stakeholders, in line with the Government's desire for deliberative regulatory policymaking, ${ }^{118}$ and instituted a bipartisan and tripartite advisory panel to assist in the formation of his report. This provided an opportunity for input from a wide range of bodies, many of whom would have been highly critical of the direction of government policy. And while Löfstedt was able to consider the submissions made via the Red Tape Challenge, these were not drawn on explicitly within the report that was produced. All of this, when combined with Löfstedt's commitment to evidence-led policymaking and independence from political interference, meant that, while the Review was open to criticism due to its relatively narrow evidence-base, ${ }^{119}$ it remained a broadly constructive document which emphasises continuity and improvement rather than wholesale change. But there were three key areas where the Review's findings seemed to directly reflect the framing of regulation as a common-sense matter of individualised, rationalized, and minimalist intervention. The focus placed onto these issues within Löfstedt's formal, authoritative report also institutionalized them (Berger and Luckmann's

\footnotetext{
${ }^{115}$ Robens, op.cit.n.17, paras. 38-41.

${ }^{116}$ Löfstedt, op.cit.n.114, 7, 32.

117 id., 92-3.

${ }^{118}$ BRE, op.cit.n.23; n.25. A list of the bodies that took part in the consultation process is provided in Löfstedt, id., Appendix C.

${ }^{119}$ James et al., op.cit.n.15, 42-5.
} 
third stage of objective reality-creation) as legitimate norms and expectations that should shape future policy decision-making, something which subsequent reactions to Löfstedt's findings have accentuated.

Firstly, a change was proposed in relation to strict liability, so that existing duties which make employers liable for injury caused by their acts or omissions regardless of fault should be amended by adding a reasonable practicability defence or by precluding liability. The 'problem' of strict liability in the health and safety context has long been overstated, ${ }^{120}$ and there are few cases where such defences do not already apply, meaning that just three examples could be referenced within the review. ${ }^{121}$ Yet the importance attached to the idea of employees using strict liability to bring frivolous claims against employers suggests that it symbolises a broader concern about paternalist interventionism infringing upon commonsense principles of individual responsibility. The Government's response to this proposal, the Enterprise and Regulatory Reform Act 2013 s.69, precluded breaches of duty under health and safety regulations from being actionable in civil law unless otherwise specified (reversing the Health and Safety at Work Act 1974 s.47's presumption of actionability unless otherwise precluded). Löfstedt himself subsequently expressed concern at the impact of a reform that was "more far-reaching than I anticipated in my recommendation"122 and that would heavily restrict the right of workers to seek compensation for injuries caused by their employers, but by this time, the embedded notion of regulation as a matter of individualised responsibility had been institutionalized further into law.

Secondly, Löfstedt proposed making exempt from health and safety law "those self-employed whose work activities pose no potential risk of harm to others", a category that was left

\footnotetext{
${ }^{120}$ W.G. Carson, 'Some Sociological Aspects of Strict Liability and the Enforcement of Factory Legislation', (1970) 33 Modern Law Rev. 396.

${ }^{121}$ Löfstedt, op.cit.n.114, 91, citing Stark v Post Office [2000] EWCA Civ 64; Dugmore v Swansea NHS Trust and another [2002] EWCA Civ 1689; Allison v London Underground Ltd. [2008] EWCA Civ 71.

${ }^{122}$ R.E. Löfstedt, Reclaiming Health and Safety for All: A Review of Progress One Year On, (2013), para.30.
} 
undefined, but was apparently envisaged as including freelance clerical workers and the like. ${ }^{123}$ Again, by institutionalizing the notion of universal, rather than rationalized, regulatory coverage as a source of unreasonableness, the Review provided an opportunity for the pursuit of more fundamental reform. The Deregulation Bill, which will imminently become law, ${ }^{124}$ proposes an exemption from health and safety law of all self-employed workers except those who work in one of a prescribed list of 'high-risk' sectors, a much more substantially deregulatory presumption than Löfstedt had envisaged. As Black and Baldwin observe, “'low risk' means, in practice, 'low priority"” and this decision reflects a set of embedded value judgements about the legitimacy of regulation ${ }^{125}$ and the emergent, 'common-sense' notion of rationalized regulation that was being used to frame the issue of health and safety. By linking self-employed risk-taking and the rejection of the 1974 Act's principle of comprehensive coverage to the concerns of the small business lobby and the perceived problem of 'regulatory creep', the Löfstedt review institutionalized the idea of nonuniversality as an evidenced principle of regulatory policymaking, something that was now a taken-for-granted norm and expectation for the future.

Thirdly, Löfstedt recommended that HSE be given oversight of local authority health and safety regulation (which largely encompasses the retail, offices, and hotel sectors) and the power to redirect enforcement in line with national models and away from "relatively lowrisk workplaces". ${ }^{126}$ Local Authorities are sometimes accused of acting as 'risk bullies', ${ }^{127}$ operating to different (overly restrictive) standards than HSE when allocating regulatory

\footnotetext{
${ }^{123}$ Löfstedt, op.cit.n.114, 43. This would mean that some 1 million self-employed workers in 'low-risk' sectors would not be under any duty to conduct risk assessments or avoid exposing others affected by their work to safety risks. This change was justified by reference to practice in other countries, and was intended to "reduce the perception that health and safety law is inappropriately applied" (p39).

124 http://services.parliament.uk/bills/2013-14/deregulation.html>.

${ }^{125}$ J. Black and R. Baldwin, 'When Risk-Based Regulation Aims Low: Approaches and Challenges', (2012) 6 Regulation \& Governance 2, 4.

${ }^{126}$ Löfstedt, op.cit.n.114, 82 .

${ }^{127}$ S. Halliday, J. Ilan, and C. Scott, 'The Public Management of Liability Risks', (2011) 31 Oxford J. Legal Studies 527, 548-9; also R. Ericson et al., Insurance as Governance (2003).
} 
resources. Löfstedt was ostensibly concerned with remedying these inconsistencies and providing greater certainty for duty-holders, but also made reference to the poor trust profile of Local Authorities, ${ }^{128}$ which regularly feature in regulatory myth stories and critical accounts of health and safety regulation. Local Authorities are portrayed as too legalistic and inclusive in their approach, focusing on breaches and workplaces that ought not to receive attention within a targeted enforcement regime, something that is incompatible with the riskdriven model of regulation that informed the Review's terms of reference. A new National Local Authority Enforcement Code ${ }^{129}$ was introduced to embed this recommendation; this restriction of the range of possibilities open to regulators constituted a process of agendasetting of accepted 'ways of doing things around here"130 within the scope of the institutionalized 'common-sense' (and anti-interventionist) approach to regulation already embedded within the policymaking process.

\section{INTERNALIZATION: THE POST-LÖFSTEDT WORLD}

The Löfstedt report was formally accepted after publication and the majority of the recommendations were promptly implemented. ${ }^{131}$ While it aimed to take a dispassionate, evidence-led approach to reform, it still provided a means by which a set of policy choices relating to a deregulatory shift could be brought into the policymaking process. The deliberative and evidence-based modes of inquiry that it adopted were not sufficient to break out of the broader framing of health and safety law that had preceded it. And while the

\footnotetext{
${ }^{128}$ R. Fairman and C. Yapp, 'Enforced Self-Regulation, Prescription, and Conceptions of Compliance within Small Business: The Impact of Enforcement', (2005) 27 Law \& Policy 491, 505-7; Halliday et al, ibid.; J. Walls, N. Pidgeon, A. Weyman, and T. Horlick-Jones, 'Critical Trust: Understanding Lay Perceptions of Health and Safety Risk Regulation', (2004) 6 Health, Risk, \& Society 133, 137.

${ }^{129}$ HSE [Great Britain, Health and Safety Executive], National Local Authority Enforcement Code, Health and Safety at Work: England, Scotland \& Wales (n.d.) <http://www.hse.gov.uk/lau/la-enforcement-code.htm>.

${ }^{130}$ Bachrach and Baratz, op.cit.n.63; Blaszin and Guldenmund, op.cit.n.30, 18.

${ }^{131}$ DWP [Great Britain, Department of Work and Pensions], The Government Response to the Löfstedt Report (2011) < https://www.gov.uk/government/uploads/system/uploads/attachment_data/file/66794/lofstedt-reportresponse.pdf $>$.
} 
recommendations that Löfstedt made were, in general, relatively incremental in nature, they have been consistently overstepped by the Government in enacting subsequent reforms, demonstrating the degree to which this frame of reference has been internalized by those involved in the policymaking process. As an accepted basic assumption about 'the best way' of doing things, the sense-making framework of regulation as red tape and interference with individual self-determination has led to an increasingly proactive pursuit of outcomes that are aligned with an ideological commitment to this 'common-sense' account of health and safety regulation. So the Löfstedt report's conclusion that "the focus should be on clarifying legal requirements...rather than cutting back on the regulations themselves" ${ }^{\prime 132}$ mutated into a Governmental undertaking to, by "implementing the recommendations...reduce the number of health and safety regulations by more than 50 per cent". ${ }^{133}$ While some of this difference of emphasis is due to subsequent political capital being made from the reform process, it also results from the validation of deregulation as a goal to be pursued by government and against which the value of a policy can be measured.

Two subsequent initiatives illustrate the embedding of this common-sense approach to regulation within the regulatory imagination, not only of policymakers and government, but also of the wider public. A 'Mythbusters Challenge Panel' was created to scrutinise disproportionate health and safety decisions referred to it by the public, and this body has ruled on 336 cases, mostly regulatory myth-based (as of December 2014). ${ }^{134}$ The invocation of citizen input here provides a means of reinforcing and internalizing the core assumption that individualized, rationalized, business-oriented decision-making is the expectation against which regulators should be measured. Citizens should seek out and report cases that do not

\footnotetext{
${ }^{132}$ Löfstedt, op.cit.n.114, 57.

${ }^{133}$ DWP, op.cit.n.131, 10. This claim as to a 50\% reduction in health and safety law was also made by Chris Grayling MP, the Employment Minister, in a House of Commons speech on 23/1/2012. This proportion subsequently rose to $85 \%<$ http://www.redtapechallenge.cabinetoffice.gov.uk/progess-to-date/>. $134<$ http://www.hse.gov.uk/myth/myth-busting/index.htm $>$. 
conform to the new orthodoxy of health and safety regulation, and the collation of these reports in a visible, high-profile form serves to verify that this understanding is right by recreating them as examples to discuss and reflect upon, thus forming part of the "routine maintenance of everyday life". ${ }^{135}$ The notion of a common-sense approach to regulation is expressed again in the Social Action, Responsibility and Heroism Bill, recently passed into law by Parliament, ${ }^{136}$ which requires a court to take into account the fact that a person who may have breached a statutory or common-law duty was acting heroically or for the benefit of society when adjudicating on their potential liability. The Bill appears to be a symbolic reaction to some of the regulatory myths discussed (and, indeed, refuted) by the Young and Löfstedt reviews ${ }^{137}$ rather than a substantively meaningful change to the law; it is best understood as an engagement with the 'realities' of the common-sense conception of health and safety regulation as a matter of undue interference with individual freedoms.

One key feature of this new social reality of health and safety regulation has been that political rhetoric around the issue has become arguably more belligerent than at any time in recent memory, with the Government "determined to stamp out the health and safety killjoys...[and] root out needless bureaucracy", ${ }^{138}$ and "kill off the health and safety culture for good...[and] get a lot of this pointless time-wasting out of the British economy and British life". ${ }^{139}$ This new climate, and the assumptions made about the value of individualised, rationalized, and business-oriented regulation have set the parameters for a series of

\footnotetext{
${ }^{135}$ Berger and Luckmann, op.cit.n.4, 169.

${ }^{136}$ The Bill has been subject to trenchant criticism along the way, notably by Lord Pannick (06 January 2015, Col. 262), who described it as "the most ridiculous piece of legislation approved by Parliament in a very long time”, and "a text that would barely muster a pass mark in GCSE legal studies"

<http://www.publications.parliament.uk/pa/ld201415/ldhansrd/text/150106-0001.htm\#15010644000364>.

137 Young, op.cit.n.3, Annex D, 49; Löfstedt, op.cit.n.114, 41.

138 “'Elf and safety myths' targeted', Guardian, 18 December 2011

<http://www.guardian.co.uk/uk/feedarticle/10000844>.

${ }^{139}$ David Cameron, Prime Minster, cited in J. Kirkup, 'Coalition plans to kill off 'health and safety monster' with limits on lawyers' fees', Telegraph, 05 January 2012 <http://www.telegraph.co.uk/news/politics/8995276/Coalition-plans-to-kill-off-health-and-safety-monster-withlimits-on-lawyers-fees.html>.
} 
subsequent developments that reflect this new social reality. The emergence of newly 'marketised' regulatory strategies, such as 'Fee for Intervention', whereby HSE will undertake cost recovery when it intervenes in response to breaches of the law, ${ }^{140}$ has been made possible by the internalization of these new norms. Within this symbolic universe, individualism and personal responsibility are seen as the fundamental basis of social and economic relations and, as with the compensation culture narrative, individuals are presented as "rationally calculating, self-interested actors" who act in accordance with the economic calculation of their own self-interest. ${ }^{141}$ Health and safety is thus reframed as a matter of selfinterested exchange, rather than a universal, welfarist social goal, and thus as a cost to be divided up and allocated between parties.

Similarly, the promulgation of a seemingly UK-influenced deregulatory agenda at European level by the High-Level (Stoiber) Group on Administrative Burdens, which recommended the adoption of key principles of regulatory minimalism, non-universality (exemption), and economic rationality to tackle excessive red tape, ${ }^{142}$ exists within the same policy frame of reference. This reflects one of Löfstedt's key recommendations, namely, that British policymakers and politicians should engage more fully with European Union-level processes and institutions to ensure that new legislation is evidence-led and risk-based. ${ }^{143}$ But the Stoiber Group is a consultative, stakeholder-led institution which was created in order to reduce burdens on business, and has long acted as a repository for deregulatory impulses and

\footnotetext{
${ }^{140}$ See <http://www.hse.gov.uk/fee-for-intervention/>. The Temple Review, a triennial government review of HSE's operations, concluded that this ran a serious risk of undermining trust in the regulator; M. Temple, Triennial Review Report: Health and Safety Executive [The Temple Review] (2014) <https://www.gov.uk/government/publications/triennial-review-report-health-and-safety-executive-2014>. ${ }^{141}$ C. Parker, 'Economic Rationalities of Governance and Ambiguity in the Criminalization of Cartels', (2012) 52 Brit. J. Criminology 974, 975.

${ }^{142}$ Formally, the High-Level Group on Administrative Burdens, which recommended, for example, that "legislation must be designed so as to achieve policy objectives most effectively and at lowest cost to society, citizens and business"; High-Level Group on Administrative Burdens, Cutting Red Tape in Europe: Legacy and Outlook (2014) < http://ec.europa.eu/smart-regulation/refit/admin_burden/docs/08-10web_cebrocuttingredtape en.pdf $>, 8$.

${ }^{143}$ Löfstedt, op.cit.n.114, 4, 63.
} 
advocacy at the European level. This mode of engagement with the UK's European partners is best understood as an effort to widen the scope of the symbolic regulatory universe constructed in the UK and embed the processes of experimentation and interaction, and thus the establishment of a dominant deregulatory agenda, at a European level. For the most part, then, rather than the measured discussions about risk that Löfstedt advocated, the reform process has created a new adversarialism around the politics of regulation, and driven the internalization of a dominant narrative of health and safety regulation which then constrains the range of possibilities that subsequent policymaking can consider. The new orthodoxy of health and safety policy is dictated by the notion of common-sense regulation as an individualised, rationalised, minimalist undertaking, and this is the frame within which all subsequent decision-making must take place.

\section{CONCLUSION: MAKING SENSE OF THE REFORM PROCESS}

The public sector reforms that have followed the post-2008 economic crisis have not simply been pragmatic cost-cutting measures; public sector budget-setting is also a regulatory tool, allowing governments to exert control over policy via the medium of money. ${ }^{144}$ The rollingback of the health and safety system during this period has ideological underpinnings that predate these spending reviews and speak to more fundamental conceptions of the role of the state, something which subsequent initiatives claiming deliberative capacity and evidencebased rigour have embedded. Central to this conception is the notion of regulation as a form of 'red tape' which stands in opposition to common-sense notions of individualism and antiinterventionism. But, as Gouldner observes, "red tape as a social problem cannot be explained unless the frame of reference employed by the individual who uses this label is

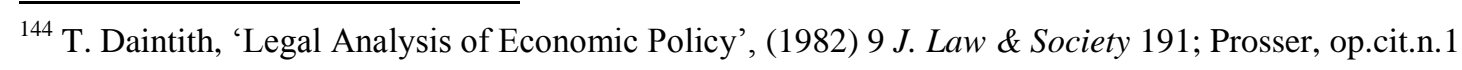


understood". ${ }^{145}$ As with other areas of debate about the governance of social and economic relations, such as those around the compensation culture, ${ }^{146}$ employment grievance procedures, ${ }^{147}$ or political lobbying, ${ }^{148}$ regulatory reform is shaped by the 'truth claims' used as framing devices by actors within the process, particularly those occupying positions of power. ${ }^{149}$ In the case of health and safety regulation, unlike these other examples, the emphasis has been less upon the advancement of an explicitly pro-business agenda, and more upon the establishment of a new orthodoxy in the framing of issues of regulation in accordance with one particular set of values.

The notion of 'common-sense' regulation was developed through experimentation with particular forms of public and government truth-claim, and introduced into the policymaking process via thinly deliberative processes of public engagement and interaction, such as the Red Tape Challenge and the Young Review. It was then institutionalized via the Löfstedt Review's official stamp of objectivity, which endorsed these truth-claims, and internalized via subsequent enactments which placed this new understanding at the centre of the ongoing reform agenda. Notions of self-reliance, state intervention as interference, economic rationality, and a rejection of universal coverage, have been transformed from doctrinal features of a particular ideological approach to regulatory analysis, into a set of foundational assumptions about what regulation can, and ought to, look like. This constitutes a significant shift, moving health and safety policymaking away from political debate about the relative merits of regulation and towards the acceptance of taken-for-granted truth-claims which exist

\footnotetext{
${ }^{145}$ Gouldner, op.cit.n.92, 411.

${ }^{146}$ Morris, op.cit.n.83.

${ }^{147}$ Edelman et al., op.cit.n.68.

${ }^{148}$ G. Gray, 'Insider Accounts of Institutional Corruption: Examining the Social Organization of Unethical Behaviour', (2013) 53 Brit. J. Criminology 533.

${ }^{149}$ S. Bittle and L. Snider, 'From Manslaughter to Preventable Accident: Shaping Corporate Criminal Liability', (2006) 28 Law \& Policy 470; Parker, op.cit.n. 141.
} 
'beyond politics'. The result is a new symbolic universe of meaning, outside the scope of direct contemplation, which exerts great influence over the direction of thought and action.

It is particularly significant to recognise the role played by deliberative engagement within this process of social reality construction. By facilitating input into policy-making, deliberative processes are intended to ensure that the interests of those outside the formal sphere of political and economic influence are represented; by retaining a commitment to values of rationality, openness, and inclusiveness, the resultant outcomes should represent the best settlement of general social interests. ${ }^{150}$ But we have seen that, in the context of health and safety policymaking at least, the use of 'thin' forms of deliberative engagement has allowed for processes of interaction and institutionalization to take place which have embedded a particular ideological approach to regulation, and which have given primacy to certain, established interests, ideas, and narratives. In part, this is because a lack of commitment to the core values of meaningful engagement set out above has allowed a social reality grounded in misperception to take hold, but it is also due to the permeability of these processes, which permit entrenched, powerful interests to shape the outcomes of the policy process. ${ }^{151}$ At every stage, a neo-liberal, small-state agenda of individualised, businessoriented, narrowly-targeted regulation has exerted considerable influence over the direction of policy to an extent that more explicit input from those advocating deregulation would be unlikely to achieve. This is the final irony; that mechanisms which open the formal, top-down process of regulatory policymaking to a wider range of interests can be so effectively redirected by the bottom-up, informal influence of processes of social reality construction which bear the imprint of a much narrower and more particular political and social agenda.

\footnotetext{
${ }^{150}$ Dahl, op.cit.n.46; Habermas (1984), op.cit.n.37; Roberts, op.cit.n.45; Solomon and Abelson, op.cit.n.46.

${ }^{151}$ Black (2001), op.cit.n.32, 42; Habermas (1984), op.cit.n.37, 166; Hendriks, op.cit.n.57; Sanders, op.cit.n.42.
} 